\title{
Amyloid Precursor Protein Mediates a Tyrosine Kinase-Dependent Activation Response in Endothelial Cells
}

\author{
Susan A. Austin, ${ }^{1}$ Mary A. Sens, ${ }^{2}$ and Colin K. Combs ${ }^{1}$ \\ Departments of ${ }^{1}$ Pharmacology, Physiology, and Therapeutics and ${ }^{2}$ Pathology, University of North Dakota School of Medicine and Health Sciences, Grand \\ Forks, North Dakota 58202
}

\begin{abstract}
Amyloid precursor protein (APP) is a ubiquitously expressed type 1 integral membrane protein. It has the ability to bind numerous

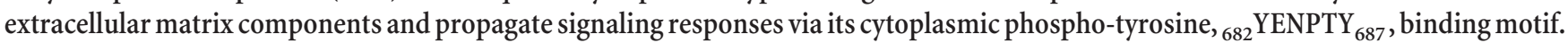
We recently demonstrated increased protein levels of APP, phosphorylated APP (Tyr682), and $\beta$-amyloid (A $\beta$ ) in brain vasculature of atherosclerotic and Alzheimer's disease (AD) tissue colocalizing primarily within the endothelial layer. This study demonstrates similar APP changes in peripheral vasculature from human and mouse $a p o E^{-/-}$aorta, suggesting that APP-related changes are not restricted to brain vasculature. Therefore, primary mouse aortic endothelial cells and human umbilical vein endothelial cells were used as a model system to examine the function of APP in endothelial cells. APP multimerization with an anti-N-terminal APP antibody, 22C11, to simulate ligand binding stimulated an Src kinase family-dependent increase in protein phospho-tyrosine levels, APP phosphorylation, and A $\beta$ secretion. Furthermore, APP multimerization stimulated increased protein levels of the proinflammatory proteins, cyclooxygenase-2 and vascular cell adhesion molecule-1 also in an Src kinase family-dependent manner. Endothelial APP was also involved in mediating monocytic cell adhesion. Collectively, these data demonstrate that endothelial APP regulates immune cell adhesion and stimulates a tyrosine kinase-dependent response driving acquisition of a reactive endothelial phenotype. These APP-mediated events may serve as therapeutic targets for intervention in progressive vascular changes common to cerebrovascular disease and AD.
\end{abstract}

\section{Introduction}

Endothelial cells play an important role in both the maintenance and inflammatory responses of the peripheral and brain vasculature. They are integral in clot formation, angiogenesis, and controlling blood pressure by mediating vasodilation or constriction. Importantly, endothelial cells are also the site for immune cell adhesion and eventual infiltration into the tissue.

Adhesion-based activation is phenotypically important in numerous cell types but particularly for immune cells and endothelial cells. Previously, we demonstrated that monocytic cells use amyloid precursor protein (APP) to mediate acquisition of an adhesion-based proinflammatory phenotype (Sondag and Combs, 2004). Endothelial cells also express APP, and surface localization increases after stimulation with proinflammatory cytokines, such as interleukin-1 $\beta$ (IL-1 $\beta$ ) (Goldgaber et al., 1989; Forloni et al., 1992). APP overexpression in endothelial cells is reportedly toxic (Jahroudi et al., 1998), and these cells express the secretase enzymes required to generate $\beta$-amyloid $(\mathrm{A} \beta)$ peptides (Davies et al., 1998). Moreover, we recently demonstrated increased immunoreactivity of APP, tyrosine 682 phosphorylated APP (pAPP),

Received June 30, 2009; revised Aug. 27, 2009; accepted Sept. 2, 2009.

This work was supported by the National Institutes of Health Grants 2P20RR017600 and 1R01AG026330 and the North Dakota National Science Foundation Experimental Program to Stimulate Competitive Research Grant RRNI EPS-0447679.

Correspondence should be addressed to Dr. Colin K. Combs, Department of Pharmacology, Physiology, and Therapeutics, University of North Dakota School of Medicine and Health Sciences, 504 Hamline Street, Neuroscience Building, Grand Forks, ND 58202. E-mail: ccombs@medicine.nodak.edu.

DOI:10.1523/JNEUROSCI.3107-09.2009

Copyright $\odot 2009$ Society for Neuroscience $\quad$ 0270-6474/09/2914451-12\$15.00/0 and $\mathrm{A} \beta$ within the cerebrovasculature, particularly in endothelial cells, of both atherosclerotic and Alzheimer's disease (AD) tissue (Austin and Combs, 2008). More importantly, adhesion of THP-1 monocytic cells was partially dependent on endothelial APP expression (Austin and Combs, 2008). These data suggest that APP regulates not only cell-cell adhesion but also modulates the proinflammatory phenotype of endothelial cells.

APP is a highly conserved and ubiquitously expressed type 1 integral membrane protein that has been suggested to function in cellular adhesion. It has the ability to interact with numerous adaptor proteins (Borg et al., 1996; Howell et al., 1999; Russo et al., 2002; Scheinfeld et al., 2002; Venezia et al., 2004) and bind several components of the extracellular matrix (Kibbey et al., 1993; Williamson et al., 1995; Beher et al., 1996). Furthermore, APP contains a conserved ${ }_{682} \mathrm{YENPTY}_{687}$ cytoplasmic motif similar to non-receptor tyrosine kinases that may be involved in propagating signaling responses.

Together, these data and our previous work demonstrating the role of APP as an adhesion receptor in immune cells supports the hypothesis that endothelial APP is involved in mediating immune cell adhesion and subsequent acquisition of a reactive phenotype that may occur during progressive vascular dysfunction seen in cardiovascular/cerebrovascular disease and AD. To further examine the role of APP within endothelial cells, we have now used primary murine aortic endothelial cells (PAECs) and human umbilical vein endothelial cells (HUVECs) as two common endothelial cell in vitro model systems. Multimerization of endothelial APP stimulated increased expression and secretion of proinflammatory proteins. Furthermore, adhesion of mono- 
cytic cells to an HUVEC monolayer was partially dependent on endothelial APP. Understanding the role of endothelial APP in regulating cell-cell adhesion and subsequent changes in endothelial phenotype may provide a therapeutic target for diseases that involve vascular dysfunction and immune cell infiltration.

\section{Materials and Methods}

Materials. The anti-APP (22C11) antibody, antivon Willebrand factor, and the mouse $\operatorname{IgG}_{1}$ isotype control were purchased from Millipore Bioscience Research Reagents. The phosphotyrosine (pTyr) antibody was purchased from Millipore Bioscience Research Reagents. The anti-A $\beta$, anti-cyclooxygenase-2 (COX-2), anti-cSrc, anti-vascular cell adhesion molecule-1 (VCAM-1) antibodies, and the horseradish peroxidase-conjugated secondary antibodies were from Santa Cruz Biotechnology. The antismooth muscle actin antibody was purchased from Novus Biologicals. Anti-APP antibody was purchased from Zymed Laboratories. The antipSrc antibody was from Cell Signaling Technologies, and the anti-smooth muscle actin antibody was from Novus Biologicals. The anti- $\alpha$-tubulin antibody was purchased from Santa Cruz Biotechnology. Anti-pAPP was generated by immunizing rabbits against the phospho- ${ }_{682}$ phosphoYENPTY $_{687}$ sequence of human $\mathrm{APP}_{695}$. Affinity-purified anti-pTyr ${ }_{682} \mathrm{APP}$ antibodies were used. 4-Amino-5-(4-chlorophenyl)-7-(t-butyl)pyrazol[3,4-d]pyrimidine (PP2) and the anti-inducible nitric oxide synthase (iNOS) antibody were purchased from Alexis Biochemicals.

Mice. App ${ }^{\text {tmlDbo} / J ~ h o m o z y g o u s ~}\left(A P P^{-/-}\right)$, Apoe ${ }^{\text {tmlUnc }} / \mathrm{J}$ homozygous $\left(a p o E^{-/-}\right)$, and wild-type (C57BL/6J) mice were purchased from The Jackson Laboratory. Mice were provided food and water ad libitum and housed in a $12 \mathrm{~h}$ light/dark cycle. Mice were killed, and abdominal aortas were collected at 8 months, immersion fixed for $24 \mathrm{~h}$ in $4 \%$ paraformaldehyde, cryoprotected through two successive 30\% sucrose changes, and serially sectioned $(40 \mu \mathrm{m})$ via freezing microtome. The investigation conforms with the Guide for the Care and Use of Laboratory Animals published by the National Institutes of Health (publication number 85-23, revised 1996).

Human tissue. Two individual human abdominal aorta samples were obtained from the University of North Dakota, Department of Pathology Tissue Bank and fixed and sectioned as described above. The investigation conforms with the principles outlined in the Declaration of Helsinki. All animal use and human tissue use was approved by the University of North Dakota Institutional Animal Care and Use Committee and Institutional Biosafety Committee/Institutional Review Board, respectively.

Tissue culture. THP-1 monocytic cells, commercially available from the American Type Culture Collection, are derived from the peripheral blood of a human with acute monocytic leukemia. THP-1 cells were grown as described previously (Austin and Combs, 2008). HUVECs were obtained from Sciencell Research Laboratories. HUVECs were grown in endothelial cell media (ECM) that was made from RPMI-1640 media supplemented with $10 \%$ FBS, $1 \%$ endothelial cell growth supplement (Sciencell Research Laboratories), and $1.5 \mu \mathrm{g} / \mathrm{ml}$ penicillin/streptomycin/neomycin. PAECs were obtained as described previously by McGuire and Orkin (1987). Briefly, the abdominal aorta was removed from 8-month-old C57BL/6 (wild-type) or $A P P^{-1-}$ mice and rinsed with HBSS. Periadventitial fat was removed, and rings $<2 \mathrm{~mm}$ were cut. These aortic explants were placed onto a matrigel (BD Biosciences) substrate in ECM for 4-7 d before explants were removed. Endothelial cells were allowed to grow for several days before collection from the matrigel using
A
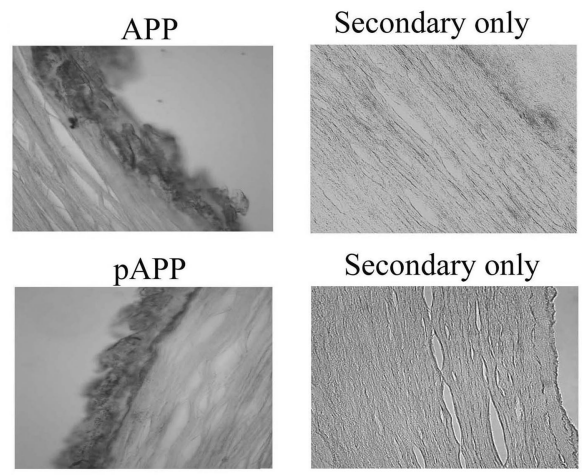

Secondary only

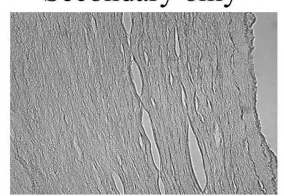

Smooth muscle actin

Secondary only
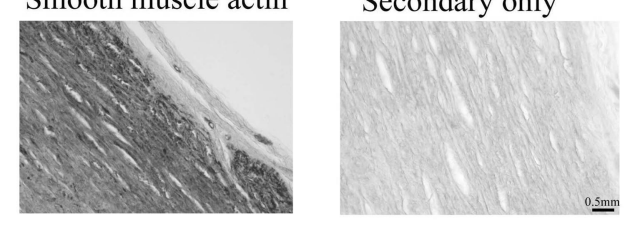
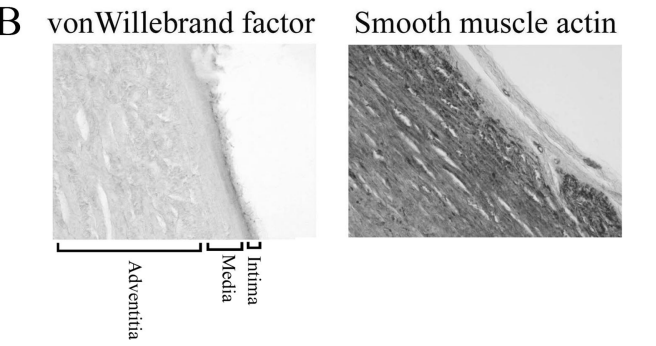

ity for APP and pAPP. A, Fixed tissue sections $(40 \mu \mathrm{m})$ of human aorta were immunolabeled with anti-APP or pAPP (Vector Blue). Tissue sections were also immunostained in the absence of primary antibodies to control for nonspecific staining from anti-rabbit secondary antibodies. $\boldsymbol{B}$, Sections were also immunolabeled with anti-von Willebrand factor, anti-smooth muscle actin, or secondary antibody only and visualized using Vector VIP as the chromagen. Magnification used $40 \times$ objective.

dispase (BD Biosciences). After collection, PAECs were then cultured on poly-L-lysine-coated tissue culture plastic or coverslips for use.

Cell stimulation. To increase the amount of surface APP on the THP-1 monocytic cells, HUVECs and PAECs were stimulated with $25 \mathrm{ng} / \mathrm{ml}$ lipopolysaccharide (LPS) for $2 \mathrm{~h}$ and $25 \mathrm{ng} / \mathrm{ml}$ tumor necrosis factor- $\alpha$ (TNF- $\alpha$ ) for $3-4 \mathrm{~h}$, respectively, at $37^{\circ} \mathrm{C}$ before use in experiments.

Cell labeling. To fluorescently label THP-1 cells for use in the adhesion assays, previously stimulated THP-1 cells were incubated with DNA labeling dye from the Cyquant proliferation assay (Invitrogen) for $10 \mathrm{~min}$ at $37^{\circ} \mathrm{C}$ before use.

APP crosslinking. Endothelial cells were collected using 0.25\% EDTA/ trypsin and plated overnight, allowing them to attach and equilibrate before use in experiments. Crosslinking of endothelial surface APP was achieved by incubating HUVECs and PAECs with or without an $\mathrm{N}$-terminal anti-APP antibody $(22 \mathrm{C} 11,1 \mu \mathrm{g} / \mathrm{ml})$ or mouse $\operatorname{IgG}_{1}(1 \mu \mathrm{g} /$ $\mathrm{ml}$ ) isotype control for $30 \mathrm{~min}$ or $24 \mathrm{~h}$ at $37^{\circ} \mathrm{C}$.

Src family kinase inhibition. PP2, a noncompetitive inhibitor of ATP, is a selective Src family kinase inhibitor that binds adjacent to the ATP binding site (Hanke et al., 1996; Zhu et al., 1999; Karni et al., 2003). To inhibit Src kinase activity, endothelial cells were pretreated with PP2 30 min before and concomitantly during duration of experiments.

Tissue immunohistochemistry. To perform immunohistochemistry, sections $(40 \mu \mathrm{m})$ were immunostained using anti-von Willebrand factor, anti-smooth muscle actin, anti-APP, and anti-pAPP and visualized using either Vector VIP, DAB, or Vector Blue as the chromagens (Vector Laboratories). Secondary antibody only staining was performed as nonspecific staining controls.

Culture immunocytochemistry. To perform immunocytochemistry, cells were fixed with $4 \%$ paraformaldehyde $\left(30 \mathrm{~min}, 37^{\circ} \mathrm{C}\right)$ and immunostained using anti-pAPP, anti-A $\beta$, anti-VCAM- 1 , anti-COX-2, antivon Willebrand factor, or anti-smooth muscle actin antibodies as

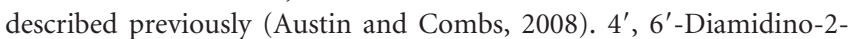
phenylindole (DAPI) was used to visualize the nucleus. Images were captured using a Carl Zeiss LSM 510 Meta confocal microscope.

Western blot analysis. Cells were stimulated as described above. Western blot analysis was performed as described previously (Austin and Combs, 2008). Optical density of protein bands from five to six independent experiments were normalized against a protein loading control ( $\alpha$-tubulin) using 


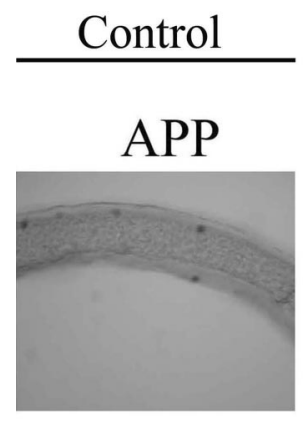

pAPP

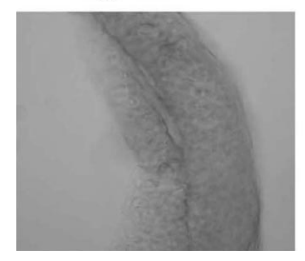

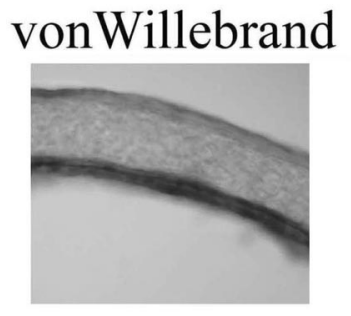

vonWillebrand

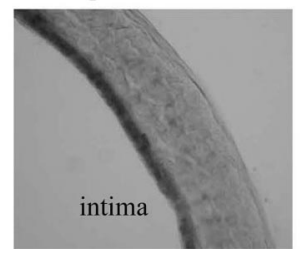

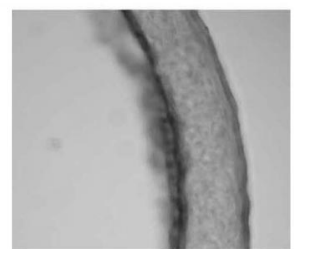

Figure 2. ApoE ${ }^{-/-}$abdominal aorta demonstrated increased immunoreactivity for APP and $\mathrm{pAPP}$, which colocalized with the endothelial marker von Willebrand factor. Fixed tissue sections $(40 \mu \mathrm{m})$ from apoE ${ }^{-/-}$and age-matched wild-type (control) mice (8 months old) were immunolabeled with either anti-APP or pAPP (Vector Blue) and von Willebrand (DAB) antibodies. Sections are representative from three animals per background. Magnification used $40 \times$ objective.

A

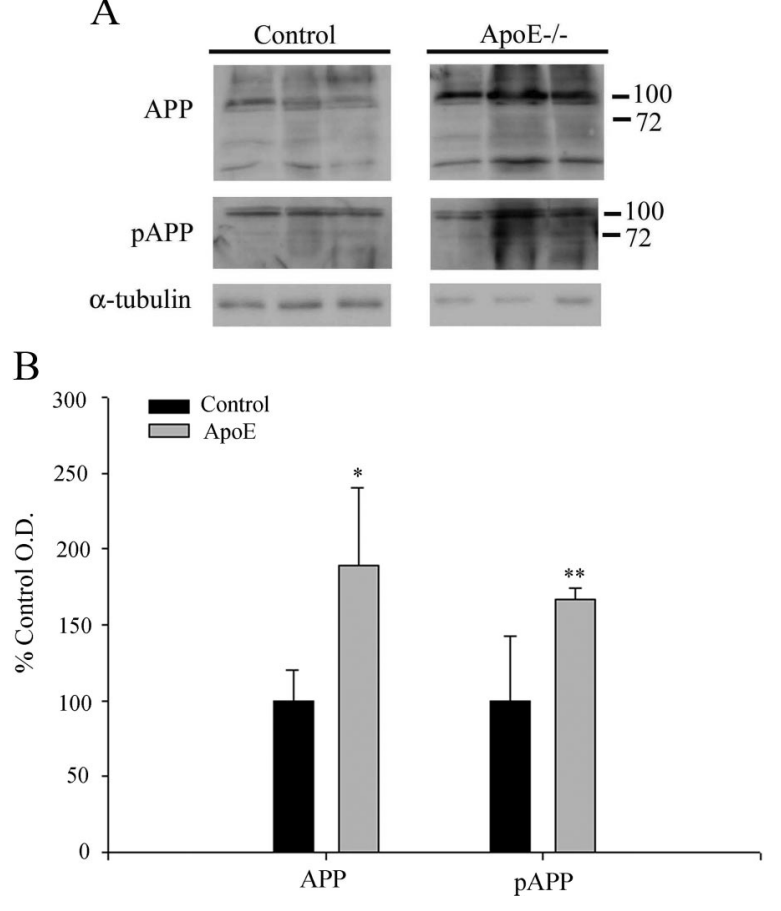

Figure 3. APP and pAPP protein levels were increased in aortas of $a p 0 E^{-/-}$mice compared with age-matched controls. A, Aortic tissue from 8-month-old $a p 0 E^{-1-}$ and wild-type control mice was lysed and quantified, and the proteins were resolved by 10\% SDS-PAGE and Western blotted using anti-APP, pAPP, and $\alpha$-tubulin (loading control) antibodies. B, Percentage change in the optical density (0.D.) of APP and pAPP protein bands from six animal samples were calculated and presented as percentage $\pm S D$ control optical density ( ${ }^{*} p<0.05,{ }^{* *} p<0.01$ from respective control).

Adobe Photoshop software (Adobe Systems), and statistical analysis was performed. Data are presented as mean \pm SD values, and statistical significance was determined by unpaired $t$ test.

Immunoprecipitation. Cells were stimulated as described above. Immunoprecipitations were done as described previously by Austin and Combs (2008). Immunoprecipitates were then used for Western blot analysis as described above.
ELISA. Media was collected from HUVECs after $24 \mathrm{~h}$ stimulation. Levels of human IL-1 $\beta$ and $\mathrm{A} \beta_{1-40}$ and $\mathrm{A} \beta_{1-42}$ were detected using commercially available ELISA kits from eBioscience per the instructions of the manufacturer. Statistical analysis of data was performed using an unpaired ANOVA with Tukey-Kramer post hoc comparison. Data are represented as mean $\pm \mathrm{SD}$ $\left({ }^{*} p<0.001\right)$.

Proliferation assay. To assess effects of APP crosslinking on cellular proliferation, we used Cyquant NF cell proliferation assay (Invitrogen). Cells were stimulated overnight, and the proliferation assay was performed according to the instructions of the manufacturer. Statistical analysis of data was performed using an unpaired ANOVA with TukeyKramer post hoc comparison. Data are represented as mean $\pm \mathrm{SD}$.

Cell viability assay. To determine cell viability after $24 \mathrm{~h}$ crosslinking stimulation, the cellular release of lactate dehydrogenase (LDH) was measured using a commercially available nonradioactive assay (Promega). Absorbance measurements were taken at $490 \mathrm{~nm}$. Statistical analysis of data was performed using an unpaired ANOVA with Tukey-Kramer post hoc comparison. Data are represented as mean $\pm \mathrm{SD}$.

Stamper-Woodruff adhesion assay. To assess tissue adhesion, a modified Stamper-Woodruff adhesion assay was used (Stamper and Woodruff, 1976). Briefly, serial aortic sections from $a p o E^{-/-}, A P P^{+/-}, A P P^{-/-}$, and $A P P^{+/+}$(wild-type/control) aortas $(40 \mu \mathrm{m})$ were mounted onto subbed slides, three aortas per background. Sections were incubated with/with-

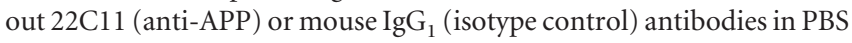
solution (PBS containing $0.5 \%$ BSA and $2 \%$ FBS) for $1 \mathrm{~h}$ at room temperature to bind surface APP. Sections were rinsed with PBS solution before a 1-h-long incubation with stimulated and labeled THP-1 cells (as described above) at room temperature with gentle agitation (50 rpm). Sections were rinsed three times with PBS solution, and adherent cells were fixed with $4 \%$ paraformaldehyde for $20 \mathrm{~min}$ at $37^{\circ} \mathrm{C}$. Images were captured using a Carl Zeiss LSM 510 Meta confocal microscope.

Quantification of adherent cells. Number of adherent cells was determined in a double-blinded manner by counting the number of cells adherent to vessel walls of serial sections in several fields of five independent sections from three animals from each background. Data are presented as mean \pm SD values, and statistical significance was determined by unpaired ANOVA with Tukey-Kramer post hoc comparison $\left({ }^{*} p<0.001\right)$.

Adhesion assay. To assess cell-cell adhesion, a monolayer of HUVECs was plated in 96-well plates and then incubated with or without the $\mathrm{N}$-terminal anti-APP antibody or $\mathrm{IgG}_{1}$ isotype control to bind APP and/or downregulate cell surface APP for $1 \mathrm{~h}$ at $37^{\circ} \mathrm{C}$. HUVECs were then incubated with a cell suspension of labeled THP-1 cells (as described above) for $1 \mathrm{~h}$ at $37^{\circ} \mathrm{C}$, followed by three rinses with ECM. Adhesion was quantitated by measuring fluorescence of adherent (fluorescently labeled) cells at $490 \mathrm{~nm}$. Statistical analysis of data was performed using an unpaired ANOVA with Tukey-Kramer post hoc comparison. Data are represented as mean $\pm \mathrm{SD}\left({ }^{\star} p<0.05\right)$.

\section{Results}

Atherosclerotic human aorta demonstrated immunoreactivity for APP and pAPP

To begin addressing a broader role of APP in the peripheral as well as brain vasculature, levels of APP in human atherosclerotic aorta were examined by immunostaining with anti-APP and pAPP antibodies. The aortas revealed strong immunoreactivity for both APP and pAPP (Fig. $1 A$ ). Indeed, using von Willebrand factor and smooth muscle actin immunoreactivity to visualize the layers of the aorta, we verified that the majority of the immu- 
A

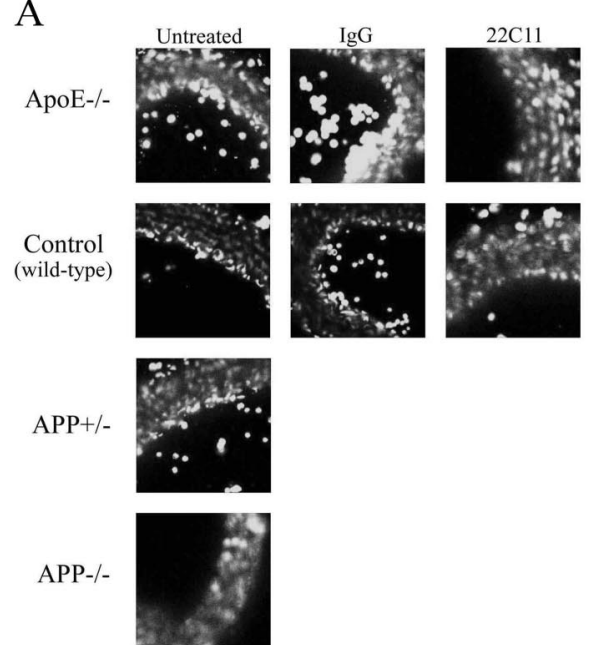

B

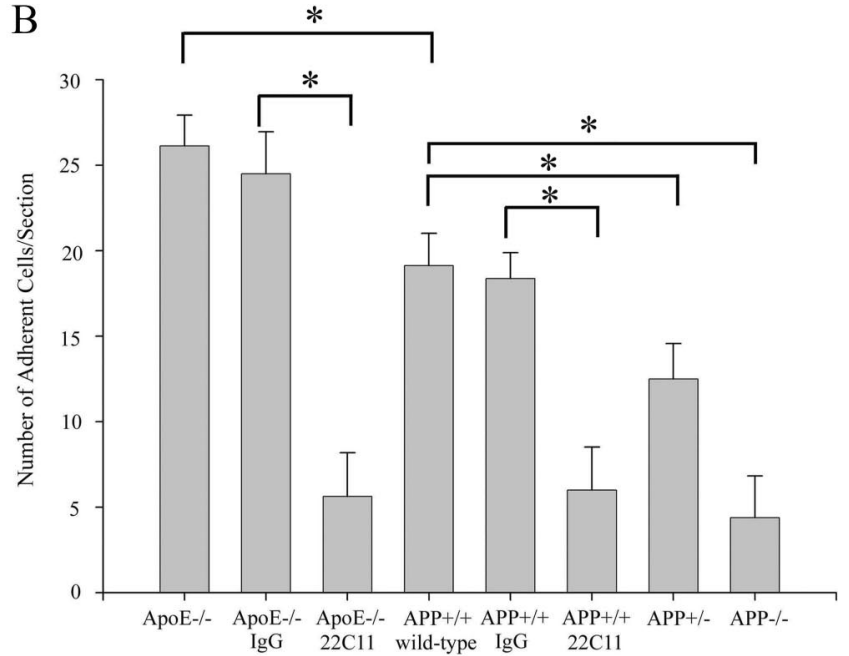

Figure 4. Adhesion of monocytic cells to aortic endothelium was partially APP dependent. $A$, THP-1 cells were pretreated for $4 \mathrm{~h}$ with $25 \mathrm{ng} / \mathrm{ml} \mathrm{LPS}$ and loaded with Cyquant dye reagent for $15 \mathrm{~min}$ before being used in a modified Stamper-Woodruff adhesion assay. $A p O E^{-/-}, A P P^{+/+}\left(C 57 B L / 6 J\right.$ wild-type/control), $A P P^{+/-}$, or $A P P^{-/-}$aortic tissue sections were incubated with or without $1 \mu \mathrm{g} / \mathrm{ml} 22 \mathrm{C} 11$ (anti-APP) or mouse lgG (isotype control) for $1 \mathrm{~h}$ at room temperature before the addition of THP-1 cell suspensions. Cells were allowed to adhere to aortic endothelium for $1 \mathrm{~h}$ with gentle agitation, non-adherent cells were rinsed away, adherent cells were fixed with $4 \%$ paraformaldehyde, and slides were prepared for viewing. $\boldsymbol{B}$, The graph represents the average number of adherent cells per aorta section per condition expressed as mean $\pm S D\left({ }^{*} p<0.001\right)$. Serial sections of the same aortas were used for each condition. The same number of sections was counted for each condition, and three animals per background were used.

A

Control

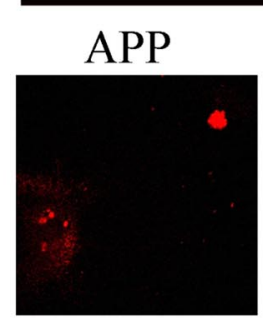

B
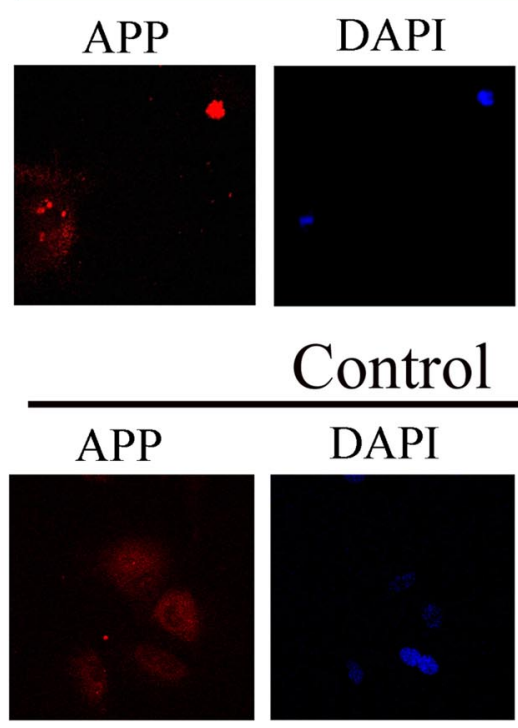

Control
DAPI

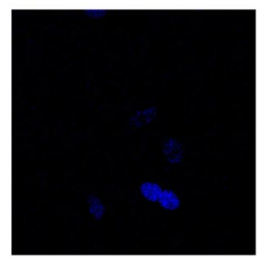

merge

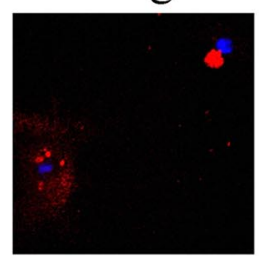

PAEC

TNF- $\alpha$ treatment

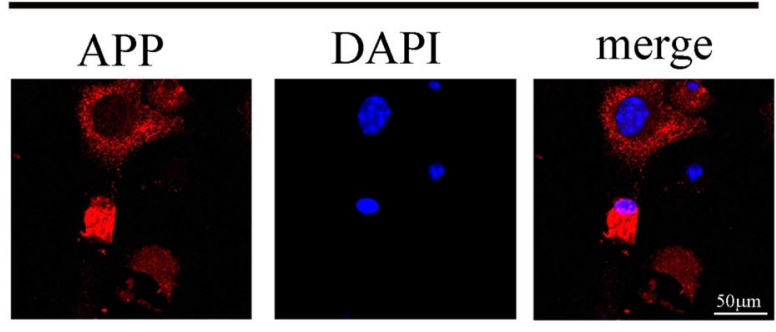

HUVEC

TNF- $\alpha$ treatment

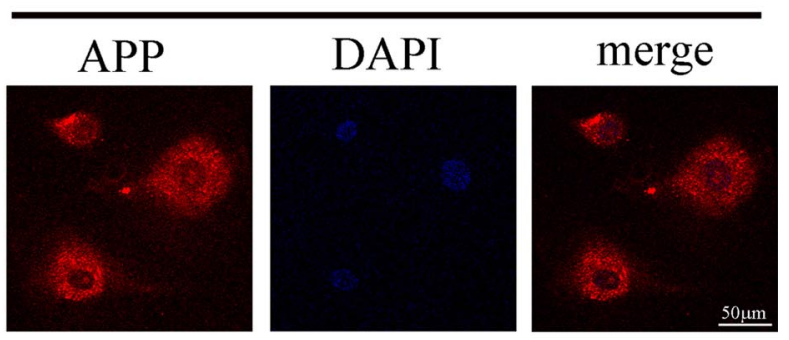

C
Endothelial marker

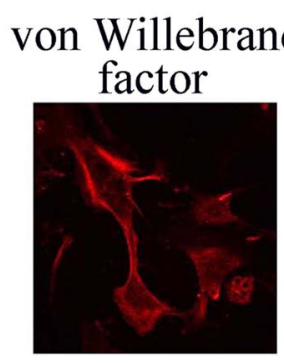

DAPI

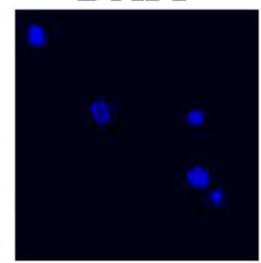

merge

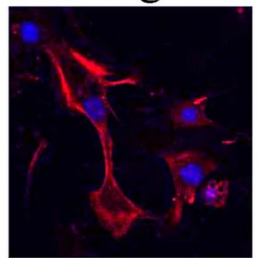

PAEC
Figure 5. Proinflammatory stimulation of endothelial cells led to increased localization of APP at the plasma membrane. PAECs $(\boldsymbol{A})$ and HUVECs $(\boldsymbol{B})$ were plated overnight in serum-free media before stimulation with $10 \mathrm{ng} / \mathrm{ml}$ recombinant TNF- $\alpha$ for 3-4 h. Cells were fixed in 4\% paraformaldehyde and immunolabeled in non-membrane permeabilizing conditions with a Texas Red-conjugated N-terminal anti-APP antibody. Nuclei were visualized using DAPI. C, PAECs were plated overnight in serum-free media, fixed with 4\% paraformaldehyde, and immunolabeled with either anti-von Willebrand factor or anti-smooth muscle actin. Images are representative of three independent experiments.
Smooth muscle,

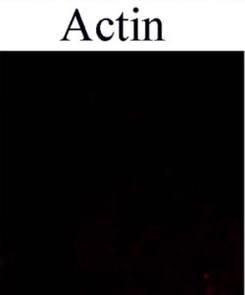

DAPI

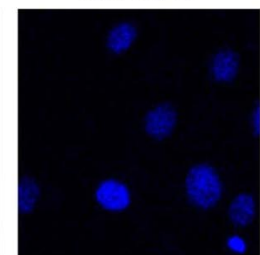

merge

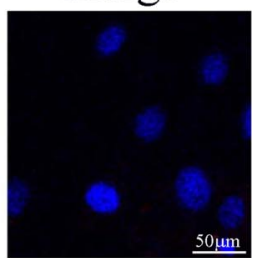

\footnotetext{
(
} 
A
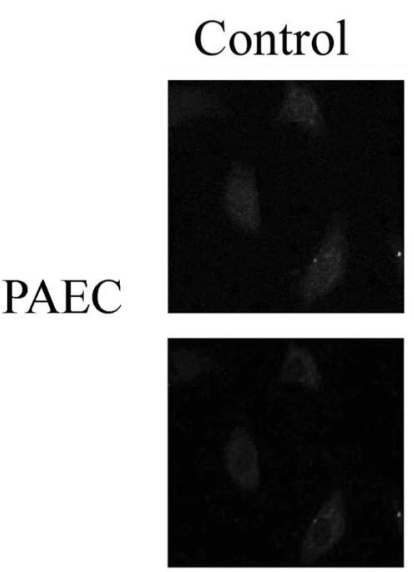

B
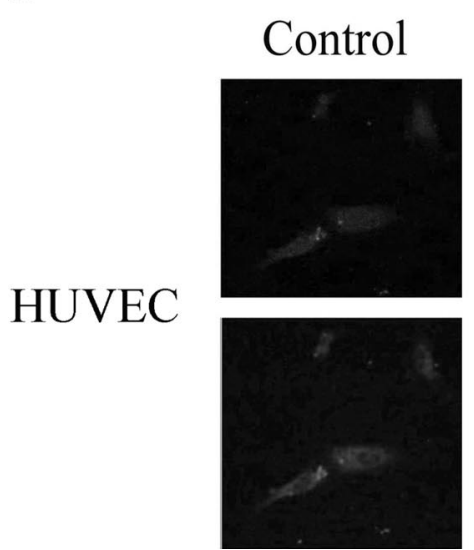
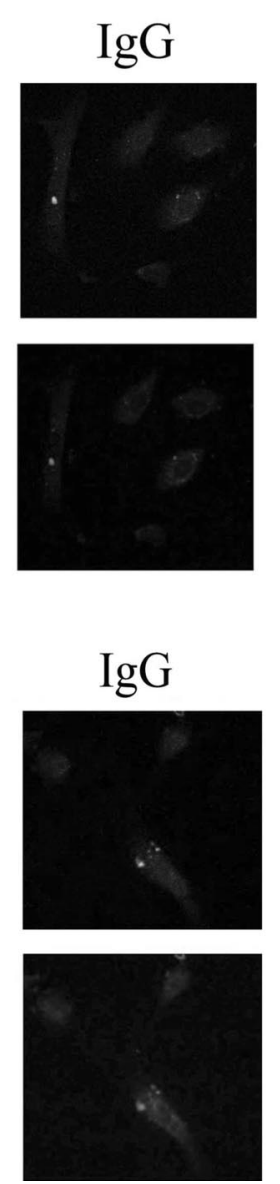

PP2
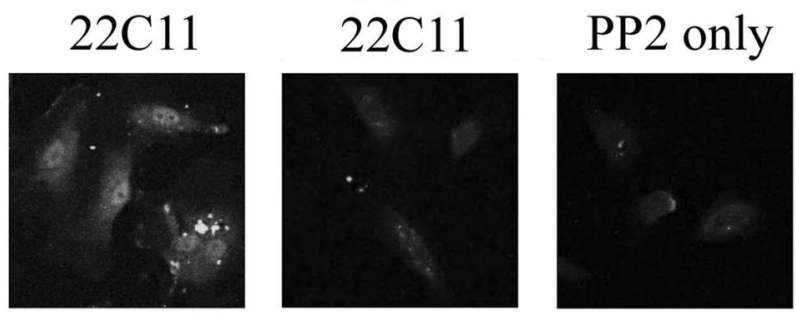

$\mathrm{A} \beta$
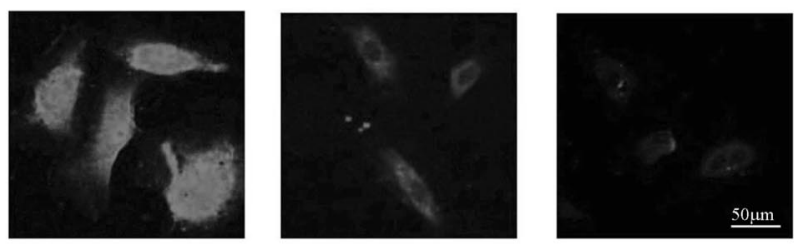

pAPP

PP2
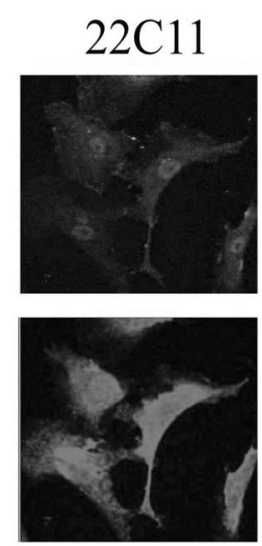

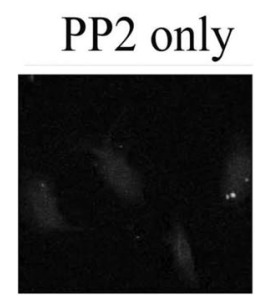

$\mathrm{A} \beta$
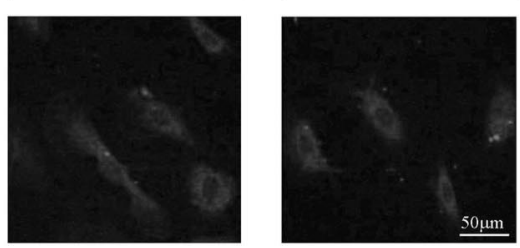

pAPP

Figure 6. APP crosslinking led to an Src kinase-dependent increase in immunologic detection of A $\beta$ generation and APP phosphorylation. PAECs $(\boldsymbol{A})$ and HUVECs $(\boldsymbol{B})$ were plated in serum-free media overnight before stimulation with or without $1 \mu \mathrm{g} / \mathrm{ml} \mathrm{lgG}_{1}$ (isotype control) or $22 \mathrm{C} 11(1 \mu \mathrm{g} / \mathrm{ml})$ for $30 \mathrm{~min}$ in the presence of absence of pretreatment and incubation with DMSO vehicle or $1 \mu \mathrm{MPP}$, an Src family kinase inhibitor. Cells were fixed in 4\% paraformaldehyde and immunolabeled with either anti-A $\beta$ or anti-pAPP antibodies. Antibody binding was visualized with FITC (A $\beta$ ) or Texas Red (pAPP) conjugated secondary antibodies. Images are representative of three independent experiments.

noreactivity was confined to the intimal layer (Fig. $1 \mathrm{~B}$ ). Interestingly, although subendothelial deposition of von Willebrand factor has been reported previously, APP/pAPP immunoreactivity also extended beyond the immediate single-cell layer of the endothelium into the intima (Nizheradze, 2006). These data confirmed that changes in APP phosphorylation and immunoreactivity observed in brain vasculature in previous work can be extended to peripheral vasculature, implying a broader role for APP in endothelial biology (Austin and Combs, 2008).

\section{Atherosclerotic abdominal aorta from $a p o E^{-/-}$mice demonstrated increased levels of APP and pAPP}

To study a more controlled model of vascular atherosclerotic changes, $a p o E^{-/-}$mice were next examined for changes in APP. Abdominal aortas were collected from $a p o E^{-/-}$and age-matched wild-type mice at 8 months of age. Previous data by Reddick et al. (1994) demonstrated that $a p o E^{-/-}$mice maintained on a standard chow diet develop increasing plaque number and complexity with age, with plaques present in the carotid arteries, abdominal aorta, and iliac arteries in animals at 9 months (Reddick et al., 1994). Therefore, abdominal aortas from 8-month-old apoE $E^{-/-}$mice were assessed to determine whether changes in APP were before robust plaque deposition. Similar to the observations from the human samples, apoE $E^{-/-}$aorta demonstrated strong APP immunoreactivity compared with wild-type controls (Fig. 2). Again, this reconfirms previous findings from both human and rodent brain vasculature (Austin and Combs, 2008). Interestingly, APP immunoreactivity in the $a p o E^{-/-}$aorta was increased in both the intimal and adventitial layers compared with controls. The adventitial change was not entirely unexpected given previous reports of increased APP expression in both fibroblasts and immune cells during stressful conditions (Johnston et al., 1994; Vehmas et al., 2004). However, only the intimal layer of the $a p o E^{-/-}$vasculature displayed increased pAPP immunoreactivity that colocalized with the endothelial marker von Willebrand factor (Fig. 2). Intimal-specific pAPP immunoreactivity suggests that APP serves unique functions within the cells of different aortic layers. To quantify the differences demonstrated by immunohistochemistry, Western blot analyses were performed. As predicted, apo $E^{-/-}$mouse aortic tissue demonstrated significantly higher levels of both APP and pAPP protein compared with wildtype controls (Fig. 3).

\section{Adhesion of monocytic cells to aortic endothelium} was partially APP dependent

Although the histological and Western blot data supported the hypothesis that APP functions to contribute to vascular dysfunction, these observations remained correlative. To begin directly defining the role of APP in endothelial cell activation and increased adhesiveness, a modified Stamper-Woodruff adhesion 
assay was used to examine adhesion of human monocytic lineage THP-1 cells to aortic endothelium from $a p o E^{-/-}$, $A P P^{+/+}$(C57BL/6 J wild-type animals), $A P P^{+/-}$, and $A P P^{-/-}$mice (Fig. 4). Based on the high degree of homology shared between the amino acid sequence of mouse and human APP, we reasoned that murine endothelial APP would interact with human monocytic proteins (Yamada et al., 1987). Significantly more monocytic cells adhered to $a p o E^{-/-}$tissue compared with the $A P P^{+/+}$wild-type controls, and this was attenuated by preincubating the aortic sections from $a p o E^{-/-}$and $A P P^{+/+}$ mice with an anti-N-terminal APP antibody, 22C11, to bind surface APP (Fig. 4). The role of APP was reconfirmed using tissue from APP genetically depleted animals. Monocytes demonstrated a gene dosage-dependent decrease in the number of adherent cells to aortic endothelium from $A P P^{+/+}$(C57BL/6J wild-type), $A P P^{+/-}$, and $A P P^{-/-}$mice (Fig. 4). Importantly, similar findings of APP-dependent adhesion have been reported from $\mathrm{AD}$ brain vasculature as well as cerebrovasculature from atherosclerotic apo $E^{-/-}$ animals, verifying again a broad role for APP in vascular biology (Austin and Combs, 2008).
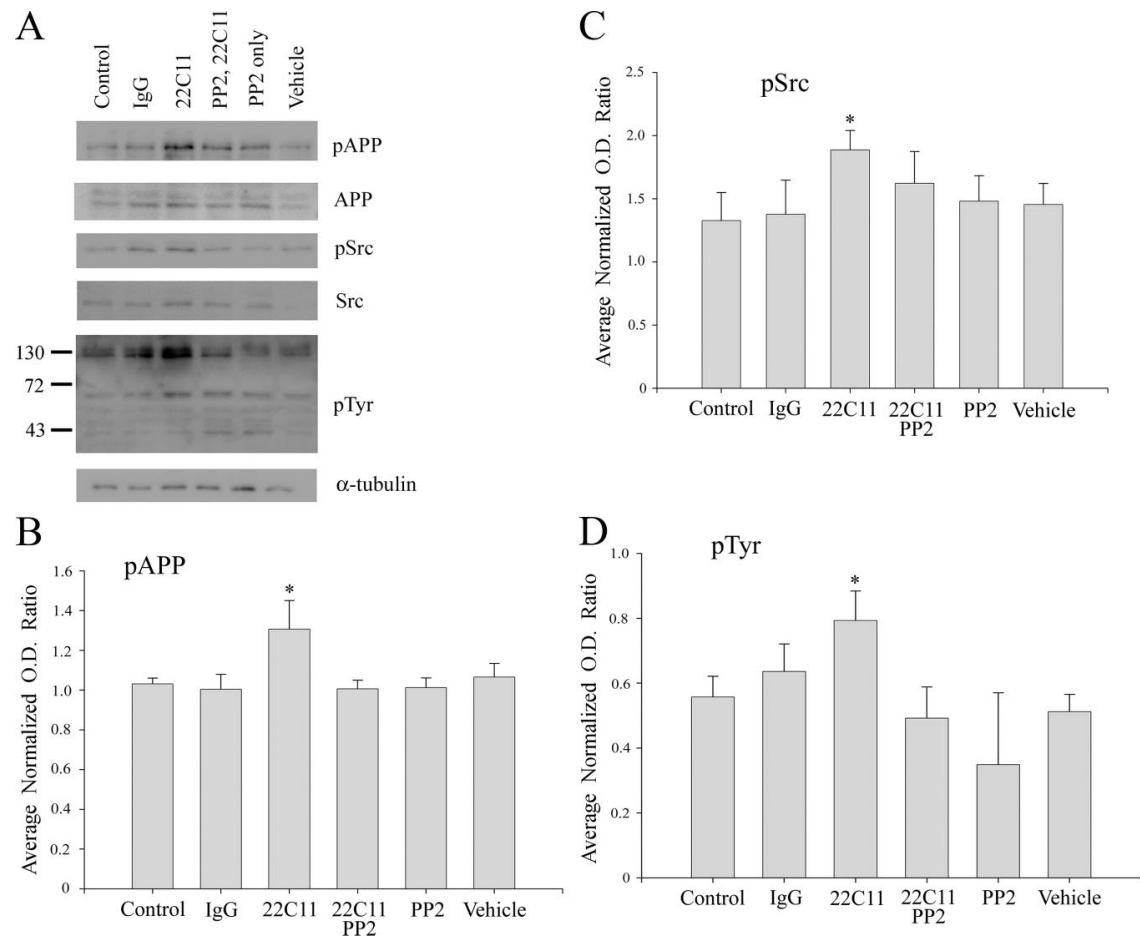

Figure 7. APP multimerization stimulated increased tyrosine, APP, and Src phosphorylation. HUVECs were treated for $30 \mathrm{~min}$ in serum-free media with or without $1 \mu \mathrm{g} / \mathrm{ml} \mathrm{IgG}_{1}$ (isotype control) or $1 \mu \mathrm{g} / \mathrm{ml} 22 \mathrm{C} 11$ in the absence or presence of pretreatment and incubation with DMSO vehicle or $1 \mu \mathrm{M}$ PP2. Cell lysates were quantified and their proteins were resolved by $10 \%$ SDS-PAGE and Western blotted $(\boldsymbol{A})$ using antibodies recognizing pAPP, APP, pSrc, Src, and $\alpha$-tubulin (loading control). Optical density (0.D.) of $\operatorname{pAPP}(\boldsymbol{B}), \operatorname{pSrc}(\boldsymbol{C})$, and pTyr $(\boldsymbol{D})$ protein bands were normalized against their respective APP, Src, and $\alpha$-tubulin bands, respectively. Optical density values were averaged from five independent experiments ( $\pm S D$ ) $\left({ }^{*} p<0.001\right.$ from lgG control).

\section{APP multimerization stimulated Src recruitment and an Src-dependent increase in phosphorylation and processing of APP in endothelial cells}

Based on the fact that endothelial expression of APP increases after proinflammatory stimulation (Goldgaber et al., 1989; Forloni et al., 1992), the current histological findings and our previous results of increased endothelial expression of APP, $\mathrm{pAPP}$, and $\mathrm{A} \beta$ in the cerebrovasculature of both atherosclerotic and AD tissue (Austin and Combs, 2008), we hypothesized that endothelial APP mediates an activating response in these cells. To begin studying the function of endothelial APP, PAECs and HUVECs were selected as well characterized in vitro model systems for assessing endothelial biology. Because minimal APP is localized to the plasma membrane basally, PAECs and HUVECs were pretreated with TNF- $\alpha$ for $3 \mathrm{~h}$ before any stimulations were performed. Nonpermeabilizing immunocytochemistry verified that TNF- $\alpha$ stimulation increased the localization of APP to the surface of endothelial cells (Fig. 5A,B). Furthermore, immunocytochemistry using antibodies recognizing von Willebrand factor, an endothelial marker, or smooth muscle actin, a smooth muscle marker, verified that the cultures were routinely at $\sim 98 \%$ purity (Fig. 5C).

To define the role of APP in the absence of a well defined stimulatory ligand, we elected to simulate ligand binding through the use of the N-terminal anti-APP antibody $22 \mathrm{C} 11$, which would induce APP multimerization and subsequently activate a signaling response. This approach has been successfully used in the past to stimulate APP-mediated signaling and proinflammatory changes in monocytic cells (Sondag and Combs, 2004). PAECs and HUVECs were stimulated with or without $22 \mathrm{C} 11$ or an $\operatorname{IgG}_{1}$ isotype control for $30 \mathrm{~min}$ to assess changes in phosphorylation

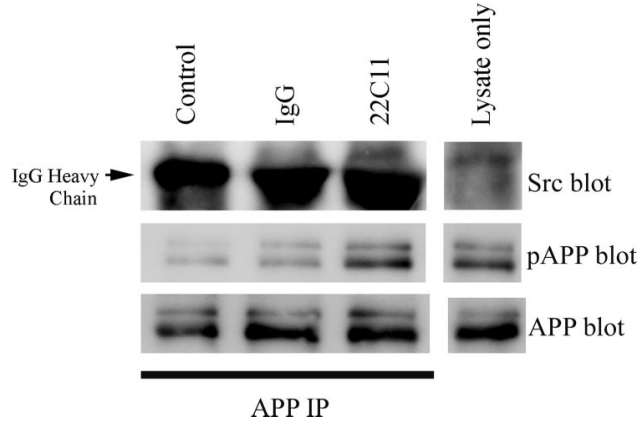

Figure 8. Multimerization of APP led to the recruitment of the tyrosine kinase Src. Coprecipitations were performed by immunoprecipitating (IP) APP in 1\% Triton X-100 buffer from HUVECs treated with or without $1 \mu \mathrm{g} / \mathrm{ml} \mathrm{lgG}$ isotype control or $1 \mu \mathrm{g} / \mathrm{ml} 22$ C11. The immunoprecipitates were resolved by 10\% SDS-PAGE and Western blotted using anti-c-Src, APP, and pAPP antibodies. Immunoprecipitations are representative of three independent experiments.

and processing of APP. Multimerization stimulated increased immunoreactivity for tyrosine phosphorylated APP as well as the proteolytic fragment $\mathrm{A} \beta$ (Fig. 6). Because previous work using brain tissue from $a p o E^{-/-}$and $\mathrm{AD}$ patients demonstrated increased association of APP with the tyrosine kinase Src (Austin and Combs, 2008), a similar signaling response was examined using the cell lines. Pretreatment of the PAECs or HUVECs with the Src family member inhibitor PP2 attenuated the multimerization-induced change in immunoreactivity for APP phosphorylation and $\mathrm{A} \beta$, demonstrating that these were Src kinase dependent (Fig. 6).

To quantify the immunocytochemical results of multimerization-induced changes in APP phosphorylation, Western blot 
A
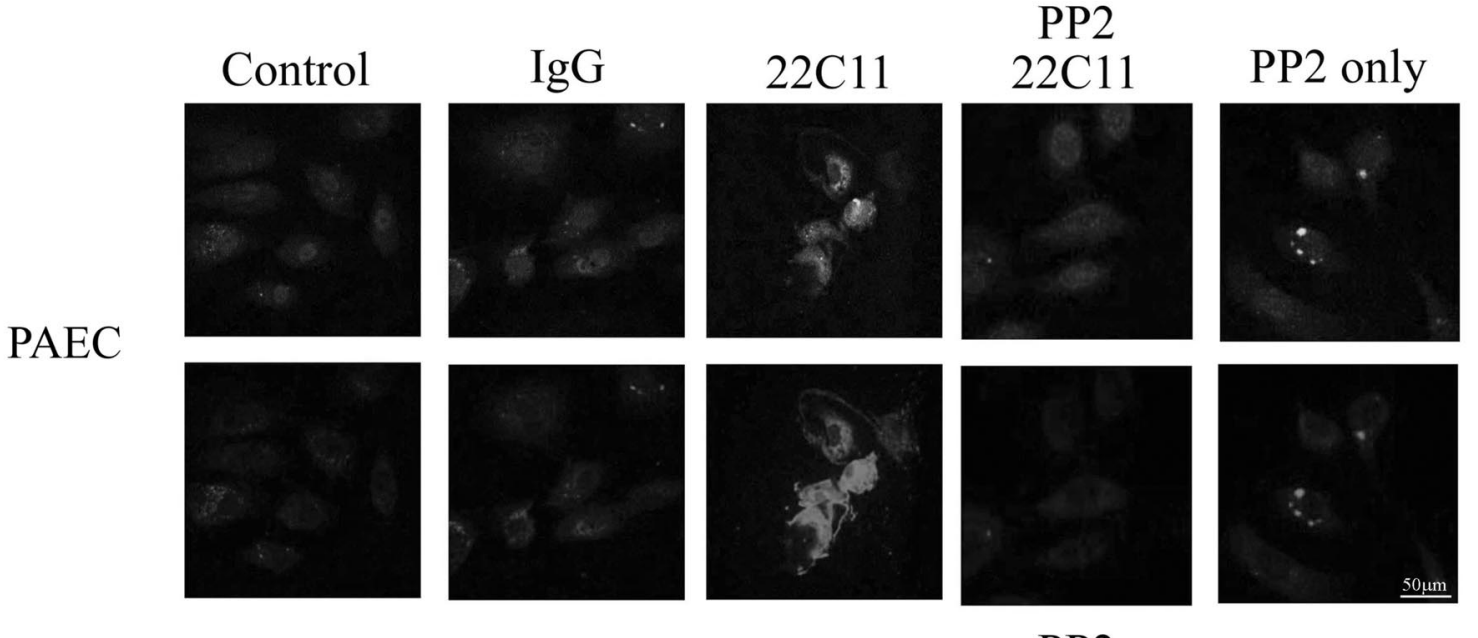

COX-2
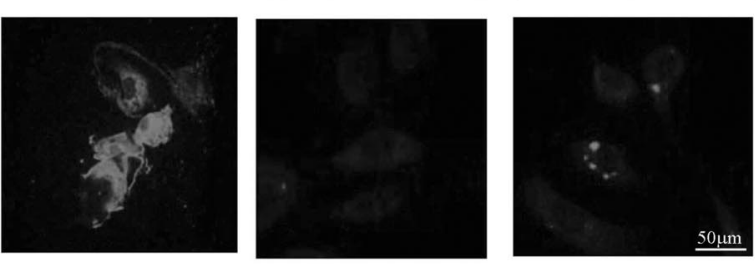

VCAM-1

\section{B}
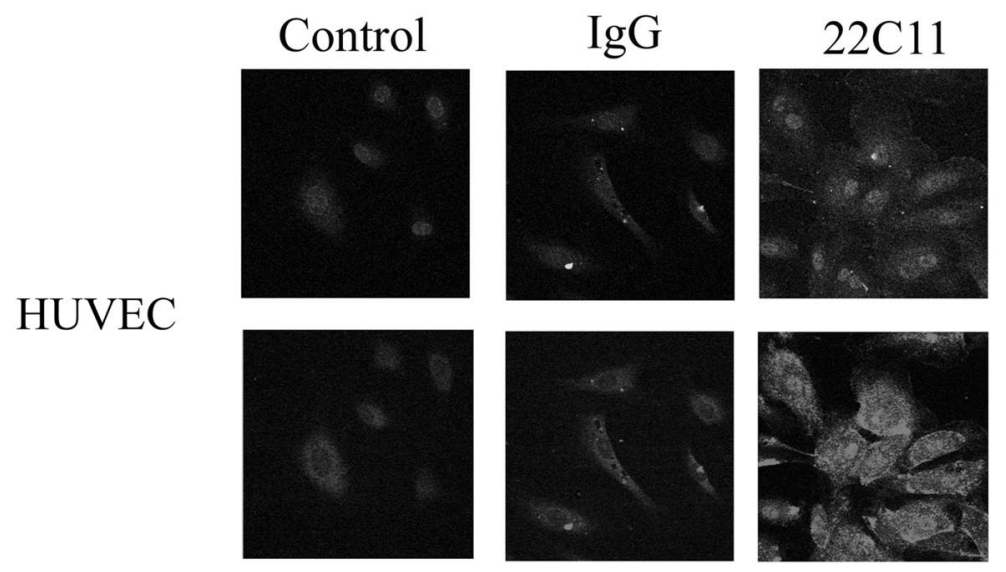

PP2
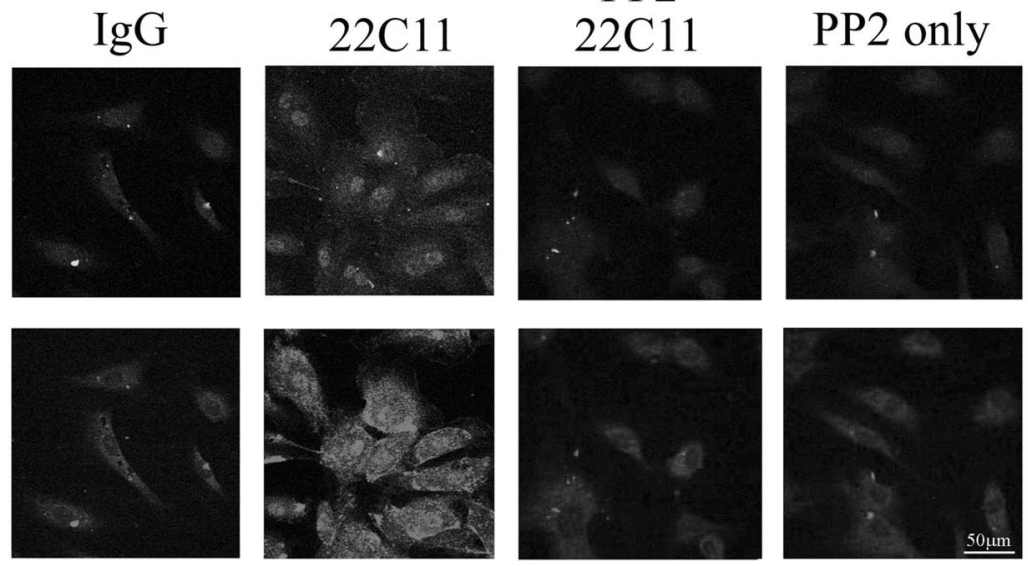

$\mathrm{COX}-2$
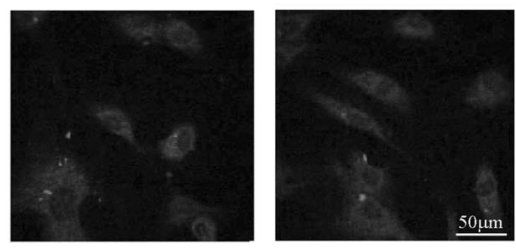

VCAM-1

Figure 9. APP crosslinking stimulated an Src kinase-dependent increase in proinflammatory mediators COX-2 and VCAM-1. PAECs $(\boldsymbol{A})$ or HUVECs $(\boldsymbol{B})$ were plated overnight before stimulation with or without $1 \mu \mathrm{g} / \mathrm{ml} \mathrm{lgG}_{1}$ (isotype control) or $1 \mu \mathrm{g} / \mathrm{ml} 22 \mathrm{C} 11$ for $24 \mathrm{~h}$ in the presence of absence of pretreatment and incubation with DMSO vehicle or $1 \mu \mathrm{M}$ PP2. Cells were fixed in $4 \%$ paraformaldehyde and immunolabeled with either anti-COX-2 or VCAM-1 antibodies. Antibody binding was visualized with FITC (COX-2) or Texas Red (VCAM-1) conjugated secondary antibodies. Images are representative of three independent experiments.

analyses of HUVECs was performed after stimulation with or without $22 \mathrm{C} 11$ or $\mathrm{IgG}_{1}$ isotype control. APP multimerization stimulated statistically increased levels of tyrosine phosphorylated proteins, specifically phosphorylation of both APP and the active, phosphorylated form of Src in an Src kinase-dependent manner (Fig. 7). These results suggested that APP multimerization lead to an association between endothelial APP and the tyrosine kinase Src, allowing for subsequent Src-mediated phosphorylation of APP. To verify an interaction of APP with Src, immunoprecipitations of APP after $22 \mathrm{C} 11$ or $\mathrm{IgG}_{1}$ isotype control stimulations were next performed. These pull-down assays indeed demonstrated an increased association of APP with Src after 22C11-induced multimerization of APP (Fig. 8). The multimerization-dependent increase in APP-Src association, Src activation (as assessed by phosphorylation), and Src-dependent APP phosphorylation in the endothelial cells strongly suggested that APP mediated a tyrosine kinase-dependent signaling response required for endothelial activation.

APP multimerization stimulated an Src-dependent increase in expression of proinflammatory proteins in endothelial cells

To address whether the APP-stimulated signaling response lead to an altered endothelial phenotype, changes in levels of common reactive endothelial marker proteins were examined after multimerization-induced activation. Immunocytochemistry and West- ern blot analyses were performed on PAECs and HUVECs after stimulation with or without $22 \mathrm{C} 11$ or $\operatorname{IgG}_{1}$ isotype control for $24 \mathrm{~h}$. APP multimerization stimulated increased immunoreactivity for both COX-2 and VCAM-1. Immunoreactivity for both COX-2 and VCAM-1 were markedly increased in the cells treated with $22 \mathrm{C} 11$ compared with the IgG $\mathrm{Ig}_{1}$ isotype control (Fig. 9). To determine whether these multimerization-induced proinflammatory changes were dependent on Src kinase activity, cells were pretreated with PP2 before stimulation. Src kinase inhibition significantly attenuated the multimerization-induced changes in immunoreactivity for COX-2 and VCAM-1 (Fig. 9).

To quantify the immunocytochemical changes, Western blot analyses of both PAECs and HUVECs after stimulation with or without $22 \mathrm{C} 11$ or $\mathrm{IgG}_{1}$ in the absence or presence of PP2 pretreatment were then performed. Western blot analyses confirmed that 22C11-induced multimerization stimulated a significant $\mathrm{Src}$ kinase-dependent increase in COX-2 and VCAM-1 protein levels but not iNOS compared with $\operatorname{IgG}_{1}$ isotype controls (Fig. 10). To further confirm the role of APP and the specificity of the $22 \mathrm{C} 11$ antibody, Western blot analyses were performed from wild-type $\left(A P P^{+/+}\right) \mathrm{C} 57 \mathrm{BL} / 6 \mathrm{~J}$ and $A P P^{-/-}$PAECs after stimulation with or without $22 \mathrm{C} 11$ or $\mathrm{IgG}_{1}$. Importantly, multimerization using the 22C11, N-terminal anti-APP antibody had no ability to increase protein levels in $A P P^{-/-}$cells (Fig. $11 A$ ). Conversely, APP stimulation significantly increased protein levels of COX-2 and 
VCAM-1 but not iNOS in wild-type cells (Fig. $11 B-D$ ). These data verified not only the specificity of the $22 \mathrm{C} 11$ antibody as an APP stimulatory ligand but also the necessity of APP-mediated signaling for the change in specific proinflammatory protein levels.

\section{APP multimerization stimulated acquisition of an Src-dependent} secretory phenotype in endothelial cells Another important aspect of a reactive endothelial phenotype is their secretion of proinflammatory mediators such as chemokines and cytokines into the extracellular environment. These secreted molecules can act in an autocrine and paracrine manner, further stimulating the endothelial cells and neighboring cells. Therefore, the ability of APP multimerization to stimulate acquisition of a reactive secretory phenotype was next determined. In particular, secreted levels of IL- $1 \beta$, a well characterized proinflammatory cytokine and activator of endothelial cells, and the APP proteolytic fragments, $\mathrm{A} \beta_{1-40}$ and $\mathrm{A} \beta_{1-42}$, were quantified. $\mathrm{A} \beta$ has been shown to have numerous effects on endothelial cells, including activation, increased adhesive properties, and death (Thomas et al., 1996; Farkas et al., 2003; Folin et al., 2005; Gonzalez-Velasquez and Moss, 2008). ELISA was used to quantify media levels of secreted IL- $1 \beta, A \beta_{1-40}$, and $\mathrm{A} \beta_{1-42}$ levels from HUVECs after stimulation with or without $22 \mathrm{C} 11$ or $\mathrm{IgG}_{1}$ isotype control. APP multimerization stimulated an Src-dependent increase in secretion of IL- $1 \beta$ as well as $A \beta_{1-40}$ (Fig. 12), whereas levels of $\mathrm{A} \beta_{1-42}$ were undetectable (data not shown). These data confirmed that the APP-stimulated, tyrosine kinase-mediated signaling response was responsible for a plethora of changes in proinflammatory protein expression and secretion in endothelial cells.

\section{Endothelial APP-mediated immune cell adhesion but not proliferation or toxicity}

As mentioned earlier, previous reports have suggested a role for APP in regulating adhesion based on its ability to bind components of the extracellular matrix (Kibbey et al., 1993; Williamson et al., 1995; Beher et al., 1996; Sondag and Combs, 2004). To broaden the understanding of endothelial APP, a more functional assessment of APP was next examined, specifically, the role of APP in mediating immune cell-endothelial cell adhesion, endothelial proliferation, and endothelial toxicity were all examined.

Because the modified Stamper-Woodruff assay (Fig. 4) had already demonstrated a requirement of APP in regulating THP-1 monocyte-endothelial adhesion in fixed aortic tissue, this cell line was used again. To remove the caveat of fixed tissue, live HUVECs were used to assess monocyte-endothelial interaction. The N-terminal anti-APP 22C11 antibody was used to bind endothelial HUVEC APP, effectively competing for subsequent interaction with the THP-1 cells. As expected, there was a significant decrease in the number of adherent monocytic cells to the HUVEC monolayer that had been preincubated with 22C11, the anti-APP antibody (Fig. 13). Interestingly, APP multimerization did not significantly affect proliferation or toxicity, demonstrating that the protein has a limited, specific function for altering the phenotype of endothelial cells (Fig. 13). These data verified that endothelial APP was involved in regulating immune cell-endothelial interaction and that the subsequent, stimulated signaling response mediated by APP lead to increased proinflammatory protein expression and secretion but not cell loss or proliferation.

\section{Discussion}

APP is a ubiquitously expressed and highly conserved protein and has been suggested to function in cell-cell or cell-matrix adhesion. We recently reported that cerebrovasculature of $\mathrm{AD}$ and atherosclerotic tissue demonstrated disease-related changes in APP expression and phosphorylation within the endothelial layer (Austin and Combs, 2008). Furthermore, adhesion of monocytic cells to brain endothelium was partially APP dependent (Austin and Combs, 2008). This study extends the brain findings to include peripheral vasculature, demonstrating a common role for APP-mediated adhesion, and tyrosine kinase-based endothelial activation may occur in vasculature in general. Using two different common in vitro endothelial systems, HUVECs and PAECs, as general models of endothelial cell behavior, we demonstrated that multimerization of APP, to simulate ligand binding, stimulated endothelial cells to acquire an Src-dependent reactive phenotype characterized by a robust increase in phosphorylation and processing of APP, increased protein levels of proinflammatory mediators such as COX-2 and VCAM-1, and increased secretion of IL- $1 \beta$ and $A \beta_{1-40}$. Moreover, adhesion of monocytic cells to aortic endothelium or an HUVEC monolayer was partially APP dependent. Together, these data suggest that 
A PAEC

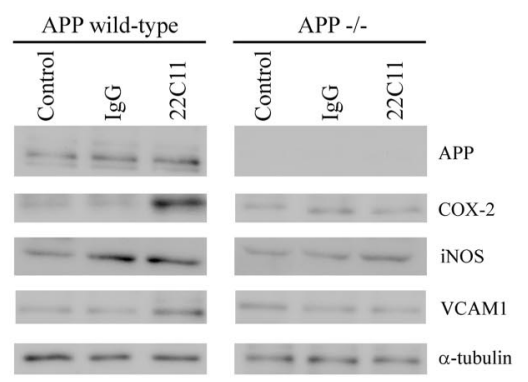

C

iNOS

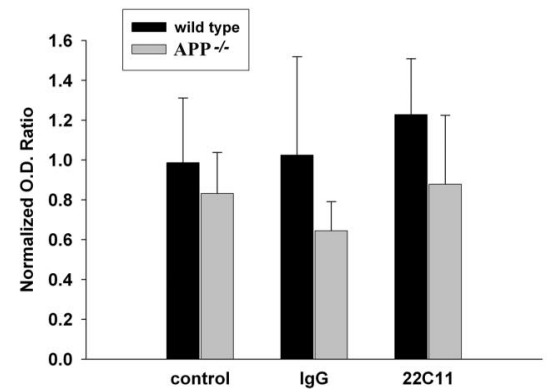

B

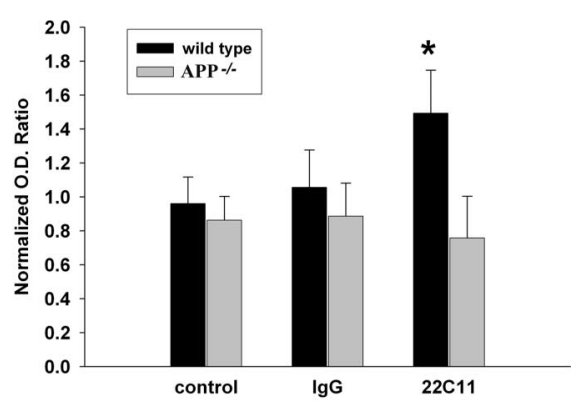

D

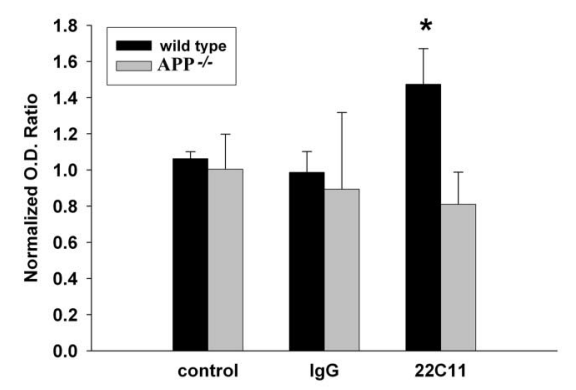

Figure 11. Crosslinking APP stimulated increased COX-2 and VCAM-1 protein levels only in wild-type endothelial cells. PAECs from wild-type $\left(57 \mathrm{BL} / 6 \mathrm{~J}\right.$ and $A P P^{-/-}$mice were treated in serum-free media for $24 \mathrm{~h}$ with or without $1 \mu \mathrm{g} / \mathrm{ml} \mathrm{lgG}_{1}$ or $1 \mu \mathrm{g} / \mathrm{ml}$ 22C11. Lysates from APP wild-type and $A P P^{-/-}$cells were quantified, and their proteins were resolved by $10 \%$ SDS-PAGE and Western blotted $(\boldsymbol{A})$ using anti-COX-2, iNOS, VCAM-1, and $\alpha$-tubulin (loading control) antibodies. Optical density (0.D.) of COX-2 $(\boldsymbol{B})$, iNOS $(\boldsymbol{C})$, and VCAM-1 $(\boldsymbol{D})$ protein bands from APP wild-type and $A P P^{-1-}$ blots were normalized against their respective $\alpha$-tubulin values and averaged from five independent experiments ( \pm SD) $\left({ }^{*} p<0.001\right.$ from lg $G_{1}$ control).
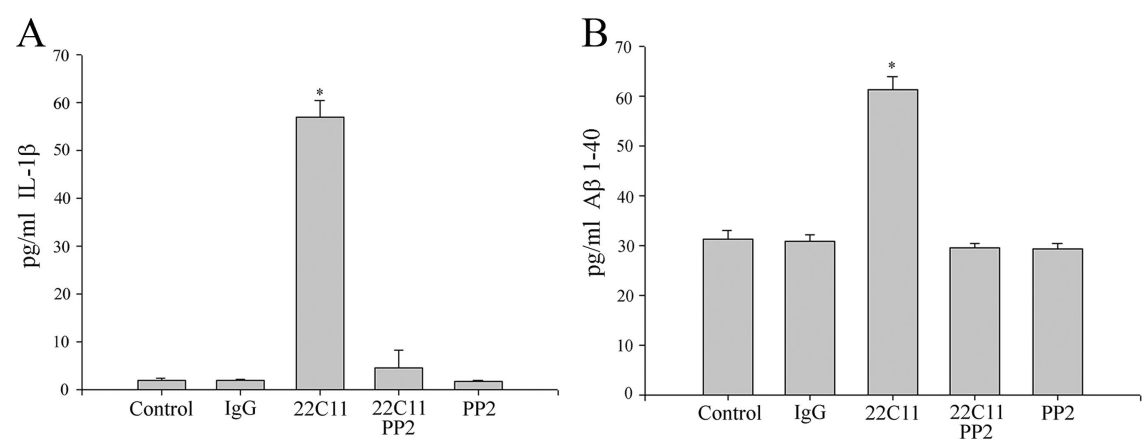

Figure 12. Crosslinking APP stimulated increased secretion of interleukin-1 $\beta$ and $A \beta_{1-40}$. HUVECs were plated in serum-free media overnight, followed by a $24 \mathrm{~h}$ stimulation with or without $1 \mu \mathrm{g} / \mathrm{ml} \mathrm{lgG}_{1}$ (isotype control) or $1 \mu \mathrm{g} / \mathrm{ml} 22 \mathrm{C} 11$ in the presence or absence of pretreatment and incubation with DMSO vehicle or $1 \mu \mathrm{m}$ PP2. Secreted values were quantified and averaged ( \pm SD) from the culture media using commercially available human IL-1 $\beta(\boldsymbol{A})$ or $A \beta_{1-40}(\boldsymbol{B})$ ELISA reagents. Data are representative of three independent experiments $\left({ }^{*} p<0.001\right.$ from $\lg G_{1}$ control).

endothelial APP mediates adhesion as well as acts as a proinflammatory receptor in these cells.

Although an N-terminal anti-APP antibody was used to simulate ligand binding, the physiologic relevance of the characterized endothelial biology will be enhanced through ultimate identification of a physiologic APP ligand. Although characterizing an APP ligand, if any, is beyond the scope of the current study, it is interesting to note that APP has been show to interact with itself as well as its cleavage products. Several groups have demonstrated an interaction of fibrillar and soluble A $\beta$ with APP, which leads to APP clustering and a stimulated signaling response (Chung et al., 1999; Lorenzo et al., 2000; Wagner et al., 2000; Van Nostrand et al., 2002; Lu et al., 2003; Gralle et al., 2009). It is possible that such an event could occur in endothelial cells in vivo. Certainly, the

endothelial results in the current study demonstrated that $\mathrm{A} \beta_{1-40}$ secretion increased after APP multimerization. Possibly, this increased $A \beta$ could act in an autocrine or paracrine feedforward manner to further stimulate the endothelial cells or neighboring cells.

Interestingly, numerous groups have demonstrated that membrane-bound APP can form homodimers and heterodimers with APP and other APP family members in a cis (same cell) or trans (opposing cell) manner (Rossjohn et al., 1999; Scheuermann et al., 2001; Lu et al., 2003; Wang and Ha, 2004; Soba et al., 2005). Furthermore, Soba et al. (2005) demonstrated APP homodimerization and heterodimerization in a trans manner lead to increased adhesion of fibroblasts. These data suggest that an interaction between APP on both monocytes and endothelial cells could be involved in mediating transdimerization adhesion and responsible for stimulating the tyrosine kinase-based activation response in endothelial cells. Alternatively, our previous work demonstrated that APP is recruited into a multimeric complex with $\beta 1$-integrin on adhesion-based stimulation of monocytes with a collagen I substrate (Sondag and Combs, 2004). These data suggest that APP may be involved in adhesion by recruitment into a complex with a more conventional adhesion receptor. Additional characterization of the exact monocyte-endothelial proteinprotein interaction that explains the dependence on APP expression for adhesion is needed to fully define the role of APP in cell-cell adhesion.

The ability of APP to stimulate acquisition of a reactive phenotype in endothelial cells has relevance to multiple disease conditions. For example, we have demonstrated disease-related changes in endothelial APP expression, phosphorylation, and processing in both brain (Austin and Combs, 2008) and peripheral vasculature in $\mathrm{AD}$ and cerebrovascular/cardiovascular disease tissue from humans and $a p o E^{-/-}$mice. Both cerebrovascular/cardiovascular disease and $\mathrm{AD}$ involve inflammation and vascular dysfunction. Immunoreactivity was not restricted to the endothelial layer alone, however, and increases were observed farther into the intimal layer. One possibility is that the proinflammatory environment in the vessels stimulated other cell types, including smooth muscle cells, to increase APP expression. Indeed, stimulation leading to increased expression of APP has been reported previously (Goldgaber et al., 1989; Shoji et al., 1990; Banati et al., 1993, 1994; Sondag and Combs, 2004). The small sample size of tissue allowed only a qualitative assessment of human APP changes, but the larger sample number of $a p o E^{-/-}$aortas permitted Western blot quantification to verify a significantly greater amount of murine APP and pAPP 

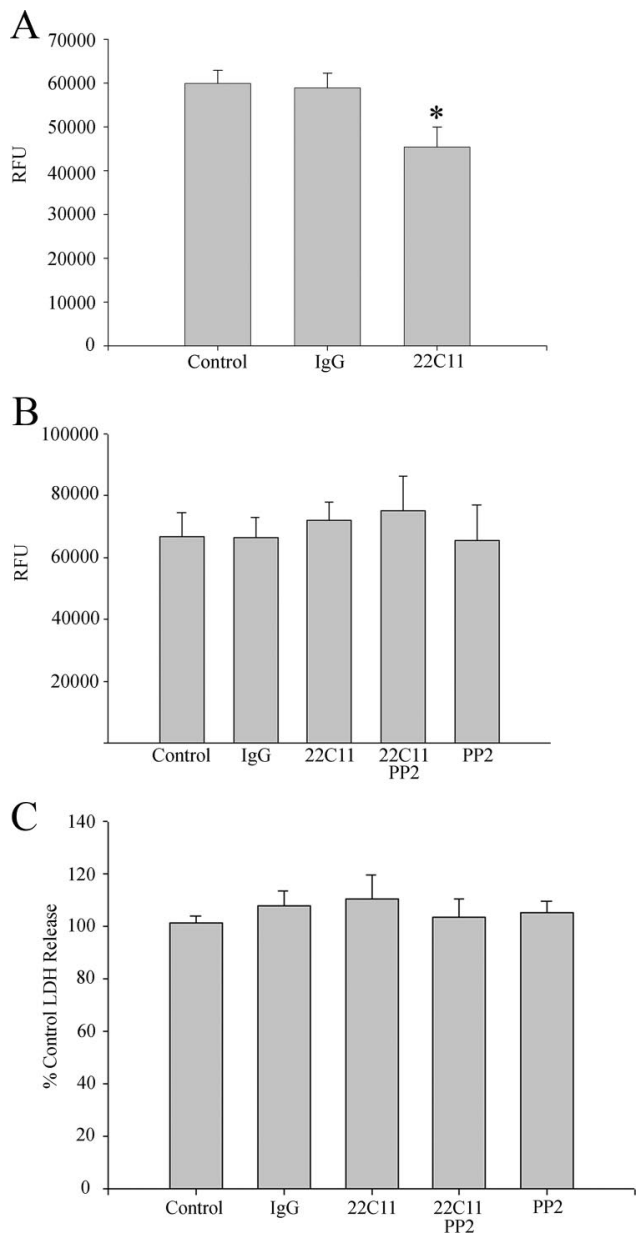

Figure 13. Adhesion of monocytic cells to HUVECs was partially APP dependent. A, THP-1 cells were pretreated for $4 \mathrm{~h}$ with $25 \mathrm{ng} / \mathrm{ml}$ LPS and then fluorescently labeled by incubation with Cyquant dye reagent for $15 \mathrm{~min}$ before being used in an adhesion assay. Briefly, HUVECs were plated in serum-free media overnight, before treatment with or without $1 \mu \mathrm{g} / \mathrm{ml} \mathrm{lgG}_{1}$ (isotype control) or $1 \mu \mathrm{g} / \mathrm{ml} 22 \mathrm{C} 11$ for $1 \mathrm{~h}$, before the addition of THP-1 cell suspensions. The cells were allowed to adhere to the HUVEC monolayer for $1 \mathrm{~h}$, and non-adherent cells were rinsed away. Adherent cells were measured by quantifying relative fluorescence units (RFU) from the labeled THP-1 cells via plate reader. Units were averaged ( $\pm S D)\left({ }^{*} p<0.05\right.$ from IgG control). Alternatively, HUVECs were plated in serum-free media overnight, before stimulation with $\lg G$ or $22 \mathrm{C} 11$ in the presence or absence of pretreatment and incubation with DMSO vehicle or $1 \mu \mathrm{MPP} 2$ for $24 \mathrm{~h}$, and cellular proliferation was examined by using a commercially available cell proliferation assay (Cyquant NF cell proliferation assay; Invitrogen) (B). C, Alternatively, cell viability was determined by averaging $( \pm S D)$ secreted $L D H$ values normalized against control secretion. Values shown are representative of three independent experiments.

levels in the $a p o E^{-/-}$animals compared with controls. Although the current study and our previous work (Austin and Combs, 2008) have only examined abdominal aorta and brain vasculature from $\mathrm{AD}$ versus control tissue and $a p o E^{-/-}$versus wild-type animals, it is intriguing to speculate that the APPrelated changes observed are not unique to any particular localization of vasculature and rather represent a common mechanism for vascular inflammation in diseases such as cardiovascular disease and AD. Indeed, it was with this general vascular role in mind that we elected to use primary mouse aortic endothelial cells and human umbilical vein endothelial cells as our model systems. We are aware that brain vascular endothelial cells may indeed differ with respect to APP function compared with either of these two cells. However, based on our previous and current results of similar endothelial APP upregulation in both brain and peripheral vasculature in AD brains and atherosclerotic tissue, it appears that these changes are common to several endothelial cell types. At the very least, these data provide a baseline for general APP function in endothelial cells and additional dissection of individual endothelial differences can now be explored.

It is important to reiterate that the study sought to understand the biology of APP as an endothelial protein. We are aware, however, of the many findings demonstrating that APP proteolytic fragments have direct ligand-type effects on endothelial cells resulting in dysfunction relevant to $\mathrm{AD}$ and cerebrovascular disease and have not attempted to readdress that biology in this study (Thomas et al., 1996; Iadecola et al., 1999; Price et al., 2001; Elesber et al., 2006). Rather, these data suggest that a parallel effect of endothelial APP function may be occurring in addition to any of those introduced by APP fragment or $\mathrm{A} \beta$ stimulation to coordinately regulate endothelial and vascular function. For example, it is interesting to speculate that one such vascular effect that might also be attributed to changes in endothelial APP may be contribution of endothelial secreted $\mathrm{A} \beta$ to vascular amyloid deposition. Cerebral amyloid angiopathy (CAA) and capillary CAA (CapCAA) are well characterized occurrences in AD brains. CAA and CapCAA involve the accumulation of predominantly $\mathrm{A} \beta_{1-40}$ in leptomeningeal and cortical arteries and capillaries, respectively (Yamaguchi et al., 1992; Attems and Jellinger, 2004; Attems et al., 2004). Therefore, it is possible that $\mathrm{A} \beta_{1-40}$ secreted by endothelial cells is one source for the vascular amyloidosis that occurs during disease in addition to peptide contributed from other cells in the brain or the vasculature.

Another intriguing possibility of consequences of increased endothelial APP may be enhanced immune cell adhesion and diapedesis. The adhesion results certainly support this notion. Based on our data, it is feasible that changes in endothelial cell surface APP in response to inflammatory changes facilitates increased immune cell attachment and diapedesis into tissue. Moreover, APP may represent one of many endothelial cell surface receptors that regulates adhesion and migration of immune cells from the blood into a target tissue. This suggests that targeting APP-mediated expression and/or signaling in the endothelial layer will provide therapeutic targets for early treatment in diseases involving vascular inflammation and/or immune cell infiltration.

Determining the timeline and histological localization of APP changes as related to vascular inflammation, atherosclerotic plaque deposition, or cerebral amyloid angiopathy will be necessary to better determine the extent of involvement of APP on the progression of vascular dysfunction as an adhesion mediator and as an endothelial proinflammatory receptor. Additional functional studies can then be performed by cell-type-specific manipulation of APP expression or its stimulated signaling response to help define the precise role of endothelial APP in diseaseassociated vascular changes. This study expands on previous reports of tyrosine phosphorylated, Src-associated APP within the cerebrovasculature of human $\mathrm{AD}$ brains and atherosclerotic $a p o E^{-/-}$mouse brains to include similar findings from peripheral aorta from humans and $a p o E^{-1-}$ mice and two different endothelial in vitro model systems. Collectively, these data offer continued support for the hypothesis that APP contributes to endothelial phenotype changes that occur during progression of vascular dysfunction in both brain and peripheral vessels in cardiovascular/cerebrovascular disease and AD. 


\section{References}

Attems J, Jellinger KA (2004) Only cerebral capillary amyloid angiopathy correlates with Alzheimer pathology: a pilot study. Acta Neuropathol 107:83-90.

Attems J, Lintner F, Jellinger KA (2004) Amyloid beta peptide 1-42 highly correlates with capillary cerebral amyloid angiopathy and Alzheimer disease pathology. Acta Neuropathol 107:283-291.

Austin SA, Combs CK (2008) Amyloid precursor protein mediates monocyte adhesion in $\mathrm{AD}$ tissue and $\operatorname{apoE}(-) /(-)$ mice. Neurobiol Aging. Advance online publication. Retrieved December 4, 2008. doi: 10.1016/j.neurobiolaging.2008.10.013.

Banati RB, Gehrmann J, Czech C, Mönning U, Jones LL, König G, Beyreuther K, Kreutzberg GW (1993) Early and rapid de novo synthesis of Alzheimer beta A4-amyloid precursor protein (APP) in activated microglia. Glia 9:199-210.

Banati RB, Gehrmann J, Kreutzberg GW (1994) Glial beta-amyloid precursor protein: expression in the dentate gyrus after entorhinal cortex lesion. Neuroreport 5:1359-1361.

Beher D, Hesse L, Masters CL, Multhaup G (1996) Regulation of amyloid protein precursor (APP) binding to collagen and mapping of the binding sites on APP and collagen type I. J Biol Chem 271:1613-1620.

Borg JP, Ooi J, Levy E, Margolis B (1996) The phosphotyrosine interaction domains of X11 and FE65 bind to distinct sites on the YENPTY motif of amyloid precursor protein. Mol Cell Biol 16:6229-6241.

Chung H, Brazil MI, Soe TT, Maxfield FR (1999) Uptake, degradation, and release of fibrillar and soluble forms of Alzheimer's amyloid beta-peptide by microglial cells. J Biol Chem 274:32301-32308.

Davies TA, Billingslea AM, Long HJ, Tibbles H, Wells JM, Eisenhauer PB, Smith SJ, Cribbs DH, Fine RE, Simons ER (1998) Brain endothelial cell enzymes cleave platelet-retained amyloid precursor protein. J Lab Clin Med 132:341-350.

Elesber AA, Bonetti PO, Woodrum JE, Zhu XY, Lerman LO, Younkin SG, Lerman A (2006) Bosentan preserves endothelial function in mice overexpressing APP. Neurobiol Aging 27:446-450.

Farkas IG, Czigner A, Farkas E, Dobó E, Soós K, Penke B, Endrész V, Mihály A (2003) Beta-amyloid peptide-induced blood-brain barrier disruption facilitates T-cell entry into the rat brain. Acta Histochem 105:115-125.

Folin M, Baiguera S, Tommasini M, Guidolin D, Conconi MT, De Carlo E, Nussdorfer GG, Parnigotto PP (2005) Effects of beta-amyloid on rat neuromicrovascular endothelial cells cultured in vitro. Int J Mol Med 15:929-935.

Forloni G, Demicheli F, Giorgi S, Bendotti C, Angeretti N (1992) Expression of amyloid precursor protein mRNAs in endothelial, neuronal and glial cells: modulation by interleukin-1. Brain Res Mol Brain Res $16: 128-134$.

Goldgaber D, Harris HW, Hla T, Maciag T, Donnelly RJ, Jacobsen JS, Vitek MP, Gajdusek DC (1989) Interleukin 1 regulates synthesis of amyloid beta-protein precursor mRNA in human endothelial cells. Proc Natl Acad Sci U S A 86:7606-7610.

Gonzalez-Velasquez FJ, Moss MA (2008) Soluble aggregates of the amyloidbeta protein activate endothelial monolayers for adhesion and subsequent transmigration of monocyte cells. J Neurochem 104:500-513.

Gralle M, Botelho MG, Wouters FS (2009) Neuroprotective secreted amyloid precursor protein acts by disrupting amyloid precursor protein dimers. J Biol Chem 284:15016-15025.

Hanke JH, Gardner JP, Dow RL, Changelian PS, Brissette WH, Weringer EJ, Pollok BA, Connelly PA (1996) Discovery of a novel, potent, and Src family-selective tyrosine kinase inhibitor. Study of Lck- and FynTdependent T cell activation. J Biol Chem 271:695-701.

Howell BW, Lanier LM, Frank R, Gertler FB, Cooper JA (1999) The disabled 1 phosphotyrosine-binding domain binds to the internalization signals of transmembrane glycoproteins and to phospholipids. Mol Cell Biol 19:5179-5188.

Iadecola C, Zhang F, Niwa K, Eckman C, Turner SK, Fischer E, Younkin S, Borchelt DR, Hsiao KK, Carlson GA (1999) SOD1 rescues cerebral endothelial dysfunction in mice overexpressing amyloid precursor protein. Nat Neurosci 2:157-161.

Jahroudi N, Kitney J, Greenberger JS, Bowser R (1998) Endothelial cell dysfunction in response to intracellular overexpression of amyloid precursor protein. J Neurosci Res 54:828-839.

Johnston JA, Cowburn RF, Norgren S, Wiehager B, Venizelos N, Winblad B,
Vigo-Pelfrey C, Schenk D, Lannfelt L, O’Neill C (1994) Increased betaamyloid release and levels of amyloid precursor protein (APP) in fibroblast cell lines from family members with the Swedish Alzheimer's disease APP670/671 mutation. FEBS Lett 354:274-278.

Karni R, Mizrachi S, Reiss-Sklan E, Gazit A, Livnah O, Levitzki A (2003) The pp60c-Src inhibitor PP1 is non-competitive against ATP. FEBS Lett 537:47-52.

Kibbey MC, Jucker M, Weeks BS, Neve RL, Van Nostrand WE, Kleinman HK (1993) beta-Amyloid precursor protein binds to the neuritepromoting IKVAV site of laminin. Proc Natl Acad Sci USA 90:10150-10153.

Lorenzo A, Yuan M, Zhang Z, Paganetti PA, Sturchler-Pierrat C, Staufenbiel M, Mautino J, Vigo FS, Sommer B, Yankner BA (2000) Amyloid beta interacts with the amyloid precursor protein: a potential toxic mechanism in Alzheimer's disease. Nat Neurosci 3:460-464.

Lu DC, Shaked GM, Masliah E, Bredesen DE, Koo EH (2003) Amyloid beta protein toxicity mediated by the formation of amyloid-beta protein precursor complexes. Ann Neurol 54:781-789.

McGuire PG, Orkin RW (1987) Isolation of rat aortic endothelial cells by primary explant techniques and their phenotypic modulation by defined substrata. Lab Invest 57:94-105.

Nizheradze K (2006) Concanavalin A, but not glycated albumin, increases subendothelial deposition of von Willebrand factor in vitro. Endothelium 13:245-248.

Price JM, Chi X, Hellermann G, Sutton ET (2001) Physiological levels of beta-amyloid induce cerebral vessel dysfunction and reduce endothelial nitric oxide production. Neurol Res 23:506-512.

Reddick RL, Zhang SH, Maeda N (1994) Atherosclerosis in mice lacking apo E. Evaluation of lesional development and progression. Arterioscler Thromb 14:141-147.

Rossjohn J, Cappai R, Feil SC, Henry A, McKinstry WJ, Galatis D, Hesse L, Multhaup G, Beyreuther K, Masters CL, Parker MW (1999) Crystal structure of the N-terminal, growth factor-like domain of Alzheimer amyloid precursor protein. Nat Struct Biol 6:327-331.

Russo C, Dolcini V, Salis S, Venezia V, Violani E, Carlo P, Zambrano N, Russo T, Schettini G (2002) Signal transduction through tyrosine-phosphorylated carboxy-terminal fragments of APP via an enhanced interaction with Shc/ Grb2 adaptor proteins in reactive astrocytes of Alzheimer's disease brain. Ann N Y Acad Sci 973:323-333.

Scheinfeld MH, Roncarati R, Vito P, Lopez PA, Abdallah M, D'Adamio L (2002) Jun NH2-terminal kinase (JNK) interacting protein 1 (JIP1) binds the cytoplasmic domain of the Alzheimer's beta-amyloid precursor protein (APP). J Biol Chem 277:3767-3775.

Scheuermann S, Hambsch B, Hesse L, Stumm J, Schmidt C, Beher D, Bayer TA, Beyreuther K, Multhaup G (2001) Homodimerization of amyloid precursor protein and its implication in the amyloidogenic pathway of Alzheimer's disease. J Biol Chem 276:33923-33929.

Shoji M, Hirai S, Harigaya Y, Kawarabayashi T, Yamaguchi H (1990) The amyloid beta-protein precursor is localized in smooth muscle cells of leptomeningeal vessels. Brain Res 530:113-116.

Soba P, Eggert S, Wagner K, Zentgraf H, Siehl K, Kreger S, Löwer A, Langer A, Merdes G, Paro R, Masters CL, Müller U, Kins S, Beyreuther K (2005) Homo- and heterodimerization of APP family members promotes intercellular adhesion. EMBO J 24:3624-3634.

Sondag CM, Combs CK (2004) Amyloid precursor protein mediates proinflammatory activation of monocytic lineage cells. J Biol Chem 279: $14456-14463$.

Stamper HB Jr, Woodruff JJ (1976) Lymphocyte homing into lymph nodes: in vitro demonstration of the selective affinity of recirculating lymphocytes for high-endothelial venules. J Exp Med 144:828-833.

Thomas T, Thomas G, McLendon C, Sutton T, Mullan M (1996) betaAmyloid-mediated vasoactivity and vascular endothelial damage. Nature 380:168-171.

Van Nostrand WE, Melchor JP, Keane DM, Saporito-Irwin SM, Romanov G, Davis J, Xu F (2002) Localization of a fibrillar amyloid betaprotein binding domain on its precursor. J Biol Chem 277:36392-36398.

Vehmas A, Lieu J, Pardo CA, McArthur JC, Gartner S (2004) Amyloid precursor protein expression in circulating monocytes and brain macrophages from patients with HIV-associated cognitive impairment. J Neuroimmunol 157:99-110. 
Venezia V, Russo C, Repetto E, Salis S, Dolcini V, Genova F, Nizzari M, Mueller U, Schettini G (2004) Apoptotic cell death influences the signaling activity of the amyloid precursor protein through ShcA and Grb2 adaptor proteins in neuroblastoma SH-SY5Y cells. J Neurochem 90:1359-1370.

Wagner MR, Keane DM, Melchor JP, Auspaker KR, Van Nostrand WE (2000) Fibrillar amyloid beta-protein binds protease nexin-2/amyloid beta-protein precursor: stimulation of its inhibition of coagulation factor XIa. Biochemistry 39:7420 -7427.

Wang Y, Ha Y (2004) The X-ray structure of an antiparallel dimer of the human amyloid precursor protein E2 domain. Mol Cell 15:343-353.

Williamson TG, Nurcombe V, Beyreuther K, Masters CL, Small DH (1995) Affinity purification of proteoglycans that bind to the amy- loid protein precursor of Alzheimer's disease. J Neurochem 65:2201-2208.

Yamada T, Sasaki H, Furuya H, Miyata T, Goto I, Sakaki Y (1987) Complementary DNA for the mouse homolog of the human amyloid beta protein precursor. Biochem Biophys Res Commun 149:665-671.

Yamaguchi H, Yamazaki T, Lemere CA, Frosch MP, Selkoe DJ (1992) Beta amyloid is focally deposited within the outer basement membrane in the amyloid angiopathy of Alzheimer's disease. An immunoelectron microscopic study. Am J Pathol 141:249-259.

Zhu X, Kim JL, Newcomb JR, Rose PE, Stover DR, Toledo LM, Zhao H, Morgenstern KA (1999) Structural analysis of the lymphocyte-specific kinase Lck in complex with non-selective and Src family selective kinase inhibitors. Structure 7:651-661. 